\section{1. 硬膜動静脈瘻の疫学・診断・病態}

徳島大学医学部脳神経外科

佐藤 浩一, 花岡 真実, 松原 俊二, 里見淳一郎, 永廣 信治

硬膜動静脈㾞は, 桑山らの全国調査により,わが国での発 生率が人口 10 万人あたり 0.28 人/年で, 諸外国と異なり cavernous sinus が最も多い発生部位であることが示された。本 疾患は，その静脈還流形態が重症度を規定する重要な因子で あることは論を俟たない，最近のトピックスは，特に静脈洞 に病変を有するタイプで血管構築がダイナミックに変化し, これに伴い臨床症状も変動するというものである，皮質静脈 逆流を持たない硬膜動静脈漊は, 経過観察, もしくは経動脈 的塞栓術により，ほとんどの症例 (98.2\%) で症状の悪化を みることなく経過するとの報告もある。しかしながら，海綿 静脈洞部硬膜動静脈㾞において経過観察もしくは経動脈的塞 栓術をうけた症例では, 後方経路である下錐体静脈洞の閉塞 性変化が起こり, 引き続いて前方経路である上眼静脈の閉塞 が進行する，つまり病変静脈洞および流出静脈の血管構築変 化が観察され, 病期進行の存在が示唆されている. 硬膜動静 脈瘻の診療には，その血管構築変化と症状変動に関する十分 な理解が必要である。

\section{2. 硬膜動静脈㾞の治療方針一外科的治療について一 \\ 奈良県立奈良病院脳神経外科 ${ }^{1}$ \\ 奈良県立医科大学脳神経外科 ${ }^{2}$ \\ 川口正一郎 1 , 橋本 宏之 ${ }^{1}$, 柿 寿右 ${ }^{2}$}

硬膜動静脈瘻 (DAVF) の外科的治療の適応と手技について 報告する。【外科的治療の適応】症候性で血管撮影上脳皮質 静脈の逆流を認める場合積極的治療を考慮し, 外科的治療は, 年齢, 臨床症状, 存在部位, 大きさ, 流入動脈, 逆流脳皮質 静脈, 罹患静脈洞の範囲, 状態などに応じ選択する，前頭蓋 窩, テント切痕部では先ず外科的治療を, 直洞, 横静脈洞, $\mathrm{S}$ 状洞，上矢状洞では血管内治療を併用し外科的治療を行う。 【外科的治療手技】逆流する脳皮質静脈の凝固離断が原則で, 罹患静脈洞と近傍硬膜の焼灼凝固, 静脈洞遊離術を行い, 閉 塞した静脈洞を摘出する場合もある。術前可能な場合, 外頸 動脈系からの流入血管塞栓術を併用する，術後，血管撮影で DAVF の消失確認と, 手術による永続的神経症状を生じない ことが肝要である，血管内治療, 定位的放射線治療の進歩で DAVF での外科的治療の役割は限定されつつあるが, 迅速確 実な病態の改善と病変の根治可能な点では他に譲れない. 各 症例で外科的治療を念頭に適切な治療の選択が必要である。

\section{3. 脳硬膜動静脈瘻のガンマナイフ治療}

小牧市民病院脳神経外科

木田 義久, 小池 讓治, 吉本 真之, 長谷川俊典

【目的】脳硬膜動静脈㾞のガンマナイフ治療の長期成績につ いて検討した。【症例と方法】当施設においてガンマナイ】 治療を受けた 24 例（男性 16 例，女性 8 例）を対象とした。 年齢の平均は 59.5 歳であり, 大半の症例は手術, あるいは血 管内治療の後の病変の残存, あるいは再発であった。病変の 局在としては, 海綿静脈洞 7 例, 横洞-S 状洞 6 例, テント 部 5 例, 前頭蓋底 2 例, 他 4 例であった. 病変の平均径は 13.5 $\mathrm{mm}$ (体積の平均は $1.7 \mathrm{cc}$ ) であり, 最大線量と辺緑線量の平 均はそれぞれ $35.2 \mathrm{~Gy}, 19.1 \mathrm{~Gy}$ であった。【結果】治療後 3〜 6 力月の早期から, 頭痛, 眼球運動障害, chemosis などの神 経症状が改善した。 MRI, MRA, 脳血管写による経過観察が 十分に得られた 17 症例 (平均 28 力月) でみると, 動静脈瘻 の消失 5 例, 著明縮小 7 例, 軽度縮小 2 例, 不変 3 例となっ た.この間 1 例において再出血が観察されている.【結論】 いまだ十分な経過観察は得られていないが，DAVF の確実な 縮小と, 消失が観察され, 神経症状も比較的早期に軽快, 消 失することから，きわめて有用な治療法と考えられた。

\section{Treatment Strategy for Dural Arteriovenous Fistula}

Centre Hospitalier de Bicêtre

Pierre Lasjaunias M. D., Ph. D.

The treatment strategy of dural arteriovenous fistula is not dependant on the existing classification or anatomo-biological approaches. The key factor is the presence of cortical venous drainage. Whether or no the sinus are patent will not modify the natural history of such angioarchitectural feature.

Davis et al have shown that dural shunt draining directly into sinuses have benign course and cannot justify any aggressive treatment in particular occlusion of normal draining sinuses.

Conversely, "malignant" forms draining into pial veins are likely to produce intra cranial hypertension, progressive deficit, seizure, or intra dural hemorrhages with or without venous infarction. In the spectrum of neurovascular diseases these lesions represent the highest annual risk of hemorrhage after discovery (Terbrugge et al).

Children present specific dural sinus malformation in which the arteriovenous shunts represent an accessory discovery, most likely induced by the epidural abnormality. The giant 